\title{
Pengaruh Infeksi Mycobacterium tuberculosis Terhadap Parameter Hematologi Anemia dan Malnutrisi Pasien TB di Puskesmas Bandar Lampung
}

\author{
Sri Ujiani ${ }^{1}$, Sri Nuraini ${ }^{2}$ \\ ${ }^{1}$ Prodi TLM Program Sarjana Terapan Poltekkes Tanjungkarang \\ ${ }^{2}$ Prodi TLM Program Diploma Tiga Poltekkes Tanjungkarang
}

\begin{abstract}
Abstrak
Tuberkulosis (TB) adalah penyakit infeksi menular yang disebabkan oleh Mycobacterium tuberculosis. Tempat masuk kuman Mycobacterium tuberculosis adalah saluran pernafasan, saluran pencernaan dan luka terbuka pada kulit. Diantara negara-negara di dunia yang mempunyai beban TB terbesar yaitu India, Indonesia, China, Philipina dan Pakistan. Menurut data Riskesdas tahun 2018 di Provinsi Lampung terdapat jumlah tersangka TB adalah 32.148 jiwa. Malnutrisi dan anemia merupakan komplikasi yang dapat terjadi pada penderita TB. Terjadinya anemia dapat dipantau dengan hasil pemeriksaan hemoglobin, jumlah eritrosit, hematokrit, dan indeks eritrosit, sedangkan keadaan malnutrisi dapat dipantau dengan hasil pemeriksaan kadar albumin. Penelitian ini bertujuan untuk mengetahui ada tidaknya pengaruh infeksi Mycobacterium tuberculosis terhadap parameter hematologi anemia dan malnutrisi pasien TB di puskesmas Bandar Lampung. Jenis penelitian yang digunakan adalah analitik, dengan desain penelitian cross sectional. Populasi penelitian adalah seluruh penderita TB yang melakukan pengobatan di beberapa puskesmas yang ada di Bandar Lampung, dengan sampel penelitian diambil dari populasi dengan menggunakan rumus besaran sampel yang bersifat representatif sebanyak 40 sampel. Analisa data yang digunakan pada penelitian ini adalah menggunakan uji One WayAnova. Hasil penelitian menunjukkan ada pengaruh infeksi Mycobacterium tuberculosis terhadap kadar $\mathrm{Hb}$. $\mathrm{Ht}, \mathrm{MCV}, \mathrm{MCH}$, dan tidak ada pengaruh terhadap jumlah eritrosit, MCHC, serta kadar albumin pada pasien TB di Puskesmas Bandar Lampung
\end{abstract}

Kata Kunci : Tuberkulosis, Parameter Anemia, Malnutrisi

\section{Effects of Mycobacterium tuberculosis Infection on Hematologic Parameters of Anemia and Malnutrition in TB Patients at Bandar Lampung Health Center}

\begin{abstract}
Tuberculosis (TB) is a contagious infectious disease caused by Mycobacterium tuberculosis. Mycobacterium tuberculosis is an entry point for the respiratory tract, digestive tract and open sores on the skin. Among the countries in the world that have the biggest TB burden are India, Indonesia, China, the Philippines and Pakistan. According to 2018 riskesdas data, in Lampung Province there are 32,148 suspected TB suspects. Malnutrition and anemia are complications that can occur in people with TB. The occurrence of anemia can be monitored by hemoglobin test results, the number of erythrocytes, hematocrit, and the erythrocyte index, while the state of malnutrition can be monitored by examination results of albumin levels. This research is a research with a group of medical biology sciences. This type of research is analytic, with cross sectional research design. The study population was all TB patients who treated at several health centers in Bandar Lampung, with the study sample taken from the population using a representative sample size formula of 40 samples. Analysis of the data used in this study is to use the One Way Anovatest. The results showed there was an influence of Mycobacterium tuberculosis infection on $\mathrm{Hb}$ levels. $\mathrm{Ht}, \mathrm{MCV}, \mathrm{MCH}$, and no effect on the number of erythrocytes, $\mathrm{MCHC}$, and albumin levels in TB patients in Bandar Lampung Health Center
\end{abstract}

Keywords: Tuberculosis, Anemia Parameters, Malnutrition

Korespondensi: Sri Ujiani, Jurusan Analis Kesehatan Politeknik Kesehatan Tanjungkarang, Jalan SoekarnoHatta No. 1 Hajimena Bandar Lampung, mobile 081540822571,e-mail sriujiani123@yahoo.com 


\section{Pendahuluan}

Tuberkulosis (TB) adalah penyakit infeksi menular yang disebabkan oleh Mycobacterium tuberculosis. Tempat masuk kuman Mycobacterium tuberculosis adalah saluran pernafasan, saluran pencernaan dan luka terbuka pada kulit. Kebanyakan infeksi TB terjadi melalui udara, yaitu melalui inhalasi droplet yang mengandung kuman-kuman basil tuberkel yang berasal dari orang yang terinfeksi (Price dan Wilson, 2006). Penyakit tuberkulosis yang disebabkan oleh kuman Mycobacterium tuberculosis ditularkan melalui udara (droplet nuclei) saat seorang pasien TB batuk dan percikan ludah yang mengandung bakteri tersebut terhirup oleh orang lain saat bernapas. Bila penderita tuberkulosis batuk, bersin, atau berbicara saat berhadapan dengan orang lain, basil tuberkulosis tersembur dan terhisap ke dalam paru orang sehat (Widoyono, 2011).

Penyebaran TB paru dari satu pasien ke pasien lainnya terjadi melalui nuclei droplet infeksius yang dapatkeluarbersama batuk, bersin, dan bicara. Faktor utama penularan infeksi adalah kedekatan atau durasi kontak serta derajat infeksius pasien. Bakteri penyebab TB (Mycobacterium tuberculosis) dapat tahan hidup pada udara kering maupun dalam keadaan dingin dan lembab. Dalam suasana lembab tersebut bakteri ini dapat tahan berharihari bahkan sampai berbulan- bulan. Beberapa faktor lainyang dapat menjadi sumber penularan ialah lingkungan, bahaya penularan terbesar terdapat di perumahan yang berpenghuni padat dengan ventilasi yang buruk, kurangnya masuk sinar matahari ke dalam ruangan dan pertukaran udara. Faktor lain yang mempengaruhi kemungkinan seseorang menjadi penderita TB adalah gizi buruk dan daya tahan tubuh yang lemah (Ida Fauziah, 2013).

Diantara negara-negara di dunia yang mempunyai beban TB terbesar yaitu India, Indonesia, China, Philipina dan Pakistan. Berdasarkan Global Report Tuberculosis tahun 2017, secara global kasus baru tuberkulosis sebesar 6,3 juta setara dengan $61 \%$ dari insiden tuberkulosis (10,4 juta). TB tetap menjadi 10 penyebab kematian tertinggi di dunia dan kematian tuberkulosis secara global diperkirakan 1,3 juta pasien (Kemenkes RI, 2018).

Sebagian besar estimasi insiden TB pada tahun 2016 terjadi di kawasan Asia Tenggara (45\%) dan 25\% nya terjadi di kawasan Afrika. Badan kesehatan dunia mendefinisikan negara dengan beban tinggi/high burden countries (HBC) untuk TB berdasarkan 3 indikator yaitu TB, TB/HIV, dan MDR-TB. Terdapat 48 negara yang masuk dalam daftar tersebut. Indonesia bersama 13 negara lain, masuk dalam daftar HBC untuk ke 3 indikator tersebut. Artinya Indonesia memiliki permasalahan besar dalam menghadapi penyakit TB. Jumlah kasus baru TB di Indonesia sebanyak 420.994 kasus pada tahun 2017 (data per 17 Mei 2018) (Kemenkes RI, 2018).

Indonesia dengan populasi penduduk sebesar 264 juta, memiliki 842.000 penduduk yang terserang penyakit TB (Kemenkes RI, 2018). Pada tahun 2017 ditemukan jumlah kasus tuberkulosis sebanyak 425.089 kasus, meningkat bila dibandingkan semua kasus TB yang ditemukan pada tahun 2016 yang sebesar 360.565 kasus. Jumlah kasus tertinggi yang dilaporkan terdapat di provinsi dengan jumlah penduduk yang besar yaitu Jawa Barat, Jawa Timur dan Jawa Tengah. Kasus TB di tiga provinsi tersebut sebesar $43 \%$ dari jumlah seluruh kasus TB di Indonesia.Tantangan yang perlu menjadi perhatian yaitu meningkatnya kasus TB-MDR, TB-HIV, TB dengan DM, TB pada anak dan masyarakat rentan lainnya. Hal ini memacu pengendalian $\mathrm{TB}$ nasional terus melakukan intensifikasi, akselerasi, ekstensifikasi dan inovasi program (Kemenkes RI, 2017).

Di Provinsi Lampung, hasil cakupan penemuan kasus penyakit TB sebanyak 6.903 orang dengan kasus baru TB paru positif adalah 4.459 orang di tahun 2016. Sedangkan di tahun 2017 hasil cakupan penemuan kasus penyakit TB meningkat menjadi 7.627 orang dengan kasus baru TB paru positif menurun menjadi 4.195 orang (Kemenkes RI, 2017). Menurut data riskesdas tahun 2018, di Provinsi Lampung terdapat jumlah tersangka TB adalah 32.148 jiwa.

Tuberkulosis paru merupakan suatu infeksi kronik jaringan paru, yang disebabkan Mycobacterium tuberculosis (Sibuea, 2009). Setiap kondisi penyakit yang berhubungan dengan peradangan, dan yang berlangsung lebih dari 1 atau 2 bulan, dapat menyebabkan anemia kronis. Anemia penyakit kronis (disebut juga anemia peradangan kronis) merupakan kondisi umum yang ditandai oleh anemia, penurunan besi serum, dan cadangan besi yang masih memadai dalam sumsum tulang ( Kiswari, 2014). Anemia penyakit kronis dipengaruhi oleh lima proses dasar, diantaranya yaitu sitokin inflamasi yang berperan sentral pada anemia penyakit kronis seperti interleukin 1 (IL-1), 
tumor necrosis factor (TNF), dan interferon $(\alpha-$ INF, $\beta$-INF, $\gamma$-INF), Semuanya menekan eritropoesis pada sumsum tulang dan juga dapat menurunkan produksi eritropoetin oleh ginjal. Biasanya ada sedikit penurunan kelangsungan hidup eritrosit (Kiswari, 2014). Penurunan produksi eritropoetin disebabkan karena produksi eritropoetin oleh ginjal terganggu, selain itu terjadi pula penyumbatan dalam transfer besi, dan penurunan respons sumsum tulang pun terjadi disebabkan karena sumsum tulang gagal untuk merespons secara bermakna terhadap terjadinya anemia (Kiswari, 2014). Anemia terjadi dapat disebabkan oleh kekurangnya zat besi dalam darah, yang dibutuhkan untuk pembentukan hemoglobin. Kekurangan besi dalam tubuh akan dapat disebabkan oleh kurangnya konsumsi makanan kaya besi (Ida Fauziah, 2013).

Pada TB dapat terjadi perubahan metabolik, kaheksia dan perubahan leptin dalam darah sehingga dapat juga menyebabkan malnutrisi. (Nasution, 2015). Infeksi TB dapat menyebabkan atau memperparah malnutrisi karena terjadi peningkatkan kebutuhan energi untuk mempertahankan fungsi normal tubuh, ini ditandai dengan peningkatan penggunaan energi saat istirahat atau resting energy expenditure (REE). Peningkatan ini mencapai $10-30 \%$ dari kebutuhan energi orang normal. Proses ini menimbulkan anoreksia akibat peningkatan produksi leptin sehingga terjadi penurunan asupan makanan (Pratomo dkk, 2012). Prevalensi anemia akan meningkat pada status nutrisi yang buruk karena malnutrisi protein menyebabkan penurunan retikulosit dan eritropoesis di sumsum tulang dan limpa (Simbolon, 2016).

Penelitian yang dilakukan oleh Martina (2012) menunjukkan bahwa terdapat hubungan antara status nutrisi dengan kejadian anemia pada pasien tuberkulosis dan didapatkan nilai $\mathrm{p}=0,01$ dengan rasio prevalensi sebesar 1,3 dan rentang interval kepercayaannya aadalah 1,09 s/d 1,7. Dalam penelitian yang dilakukan oleh Shiddiqi (2016) menunjukkan adanya efek kadar albumin terhadap perbaikan klinis pasien TB dengan $(p=0,026)$. Sehingga disimpulkan bahwa kadar albumin mempengaruhi perbaikan klinis pasien TB (Shiddiqi, 2016).

Anemia adalah keadaan dimana rendahnya jumlah sel darah merah, kadar hemoglobin, dan hitung sel darah merah, kadar hemoglobin dan nilai hematokrit (Anny Thuraidah, 2017). Anemia berarti kurangnya hemoglobin di dalam darah, yang dapat disebabkan oleh jumlah sel darah merah yang terlalu sedikit atau jumlah hemoglobin dalam sel yang terlalu sedikit (Sadikin, 2011). Penurunan status gizi atau status nutrisi yang buruk karena malnutrisi protein tercermin dari kadar albumin dalam serum. (Prastowo, 2016).

\section{Metode}

Jenis penelitian ini merupakan penelitian analitik. Desain penelitian yang digunakan adalah cross sectional. Variabel yang digunakan dalam penelitian ini meliputi variabel dependent yaitu kadar hemoglobin, kadar hematokrit, jumlah eritrosit, indeks eritrosit (MCV, MCH, MCHC), dan kadar albumin, sedangkan variabel independent adalah infeksi Mycobacterium tuberculosis yang diamati dari hasil pemeriksaan BTA berdasarkan derajat/level BTA.

Penelitian dilaksanakan di 7 Puskesmas yang ada di Bandar Lampung, yaitu Puskesmas Raja Basa Indah, Puskesmas Simpur, Puskesmas Kemiling, Puskesmas Gedong Air, Puskesmas Panjang, Puskesmas Sukaraja, dan Puskesmas Kedaton. Waktu penelitian dilaksanakan pada bulan Juni sampai dengan November 2019.

Populasi dalam penelitian ini adalah seluruh pasien TB yang belum melakukan pengobatan di puskesmas Raja Basa Indah, Puskesmas Simpur, Puskesmas Kemiling, Puskesmas Gedong Air, Puskesmas Panjang, Puskesmas Sukaraja, dan Puskesmas Kedaton. Jumlah sampel yang digunakan dalam penelitian ini sebanyak 40 pasien TB.

Pada penelitian ini peneliti melakukan penelitian dengan langkah Peneliti melakukan pengambilan data sekunder dengan melihat pada rekam medic pasien berdasarkan nama, nomor rekam medik, dan data berupa hasil pemeriksaan BTA.

Pengambilan data primer dilakukan dengan melakukan pengambilan darah pada pasien TB dan selanjutnya dilakukan pemeriksaan kadar hemoglobin, hitung jumlah eritrosit, nilai hematokrit, indeks eritrosit (MCV, MCH, MCHC), dan kadar albumin dengan alat laboratorium pada Laboratorium Patologi Klinik RSUD Dr. H. Abdul Moeloek Provinsi Lampung.

\section{Hasil}

Hasil penelitian yang telah dilakukan pada 40 penderita tuberkulosis di beberapa puskesmas yang ada di Bandar Lampung ini, adalah sebagai berikut : 
Tabel 1. Distribusi Frekuensi Parameter Hematologi Anemia dan Malnutrisi Pasien TB di Puskesmas Bandar Lampung

\begin{tabular}{cccccccc}
\hline Nilai & $\mathrm{Hb}(\mathrm{g} / \mathrm{dL})$ & $\mathrm{Ht}(\%)$ & $\begin{array}{c}\text { RBC } \\
(\mathrm{juta} / \mathrm{mL})\end{array}$ & MCV (fL) & MCH (pg) & $\begin{array}{c}\text { MCHC } \\
(\%)\end{array}$ & $\begin{array}{c}\text { Albumin } \\
(\mathrm{gr} / \mathrm{dL})\end{array}$ \\
\hline Rata-rata & 11,9 & 34 & 4,4 & 77 & 27 & 35 & 4,1 \\
Tertinggi & 17,7 & 53 & 5,7 & 95 & 38 & 38 & 5,4 \\
Terendah & 6,6 & 18 & 2,3 & 52 & 19 & 33 & 3,2 \\
\hline
\end{tabular}

Tabel 1. menunjukkan bahwa rerata kadar $\mathrm{Hb}$ pada 40 sampel pasien $\mathrm{TB}$ di Puskesmas Bandar Lampung adalah 11,9 gr/dL, dengan kadar $\mathrm{Hb}$ tertinggi 17,7 gr/dL dan terendah 6,6 gr/dL, rerata kadar $\mathrm{Ht} 34 \%$, dengan kadar tertinggi 53\% dan terendah $18 \%$. Rerata jumlah sel eritrosit 4,4 juta/mL, dengan jumlah tertinggi $5,7 \mathrm{juta} / \mathrm{mL}$ dan terendah 2,3 juta/mL. Untuk indeks eitrosit nilai rerata MCV $77 \mathrm{fL}, \mathrm{MCH} 27 \mathrm{pg}$, MCHC 35\%, dengan nilai tertinggi MCV $95 \mathrm{fL}, \mathrm{MCH} 38 \mathrm{pg}, \mathrm{MCHC}$ $38 \%$, dan nilai terendah MCV $52 \mathrm{fL}, \mathrm{MCH} 19$ pg, MCHC 33\%. Sedangkan rerata kadar albumin adalah 4,1 gr/dL, kadar tertinggi 5,4 $\mathrm{gr} / \mathrm{dL}$ dan terendah $3,2 \mathrm{gr} / \mathrm{dL}$.

Tabel 2. Persentase Pasien TB Berdasarkan Status Anemia dan Malnutrisi di Puskesmas Bandar Lampung

\begin{tabular}{lcc}
\hline \multicolumn{1}{c}{ Status } & $\begin{array}{c}\text { Jumlah } \\
\text { Sampel }\end{array}$ & Persentase (\%) \\
\hline Anemia & 32 & 80 \\
Tidak Anemia & 8 & 20 \\
Malnutrisi & 3 & 7,5 \\
Tidak & 37 & 92,5 \\
malnutrisi & & \\
\hline
\end{tabular}

Tabel 2. menunjukkan pada 40 sampel pasien TB di Puskesmas Bandar Lampung yang mengalami anemia sebanyak 32 sampel $(80 \%)$, dan yang tidak anemia sebanyak 8 sampel (20\%). Sampel yang mengalami malnutrisi dari 40 sampel sebanyak 3 orang $(7,5 \%)$ dan yang tidak mengalami malnutrisi sebanyak 37 orang $(92,5 \%)$.

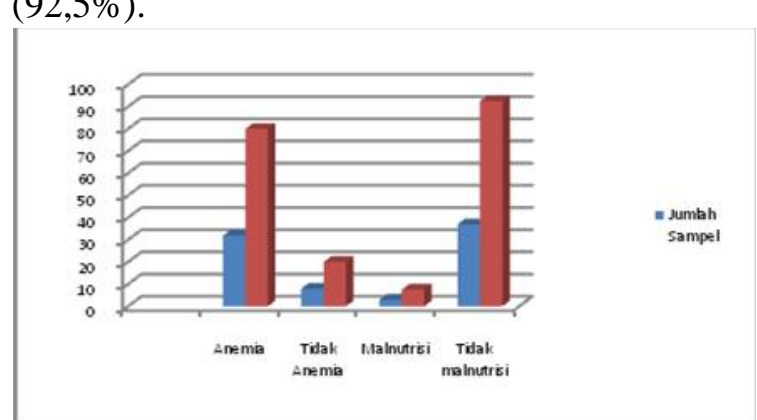
Gambar 1. Persentase Status Pasien TB di Puskesmas Bandar Lampung berdasarkan parameter hematologi anemia dan albumin

Gambar 1 menunjukkan perbedaan angka pada jumlah dan persentase kejadian anemia dengan yang tidak anemia pasien $\mathrm{TB}$ di puskesmas Bandar Lampung yang sangat signifikan. Begitu pula perbedaan angka jumlah dan persentase terjadi pada keadaan malnutrisi dengan yang tidak malnutrisi, dimana yang tidak mengalami malnutrisi lebih banyak dibandingkan dengan yang mengalami malnutrisi.

Tabel 3. Rerata Kadar Hb, Ht, Eritrosit, MCV, MCH, MCHC, Albumin berdasarkan derajat BTA (+)

\begin{tabular}{lcccccccc}
\multirow{2}{*}{ Derajat BTA } & $\begin{array}{c}\text { Jumlah } \\
\text { Sampel }\end{array}$ & $\begin{array}{c}\mathrm{Hb} \\
(\mathrm{gr} / \mathrm{dL})\end{array}$ & $\begin{array}{c}\mathrm{Ht} \\
(\%)\end{array}$ & $\begin{array}{c}\text { Eritrosit } \\
(\mathrm{juta} / \mathrm{mL})\end{array}$ & $\begin{array}{c}\text { MCV } \\
(\mathrm{fL})\end{array}$ & $\begin{array}{c}\mathrm{MCH} \\
(\mathrm{pg})\end{array}$ & $\begin{array}{c}\text { MCHC } \\
(\%)\end{array}$ & $\begin{array}{c}\text { Albumin } \\
(\mathrm{gr} / \mathrm{dL})\end{array}$ \\
\hline+ & 8 & 13,6 & 39 & 4,7 & 82,4 & 28,9 & 34,8 & 4,1 \\
++ & 14 & 11,6 & 33 & 4,2 & 79,1 & 28,6 & 35,2 & 4,2 \\
+++ & 18 & 11,4 & 32 & 4,5 & 72,6 & 25,5 & 35,2 & 4,0 \\
\hline
\end{tabular}

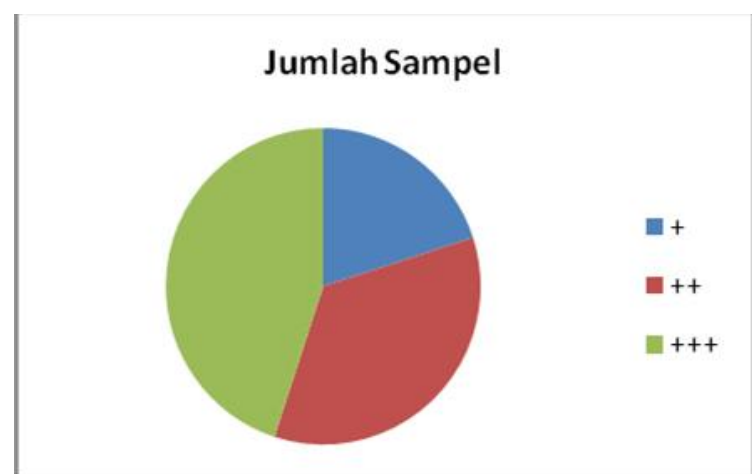

Gambar 2. Grafik Cluster Sampel Berdasarkan Derajat BTA Pasien TB di Puskesmas Bandar Lampung
Pada tabel 3 dan gambar 2 nampak bahwa pasien TB di puskesms Bandar Lampung yang datang ke puskesmas dan baru terdeteksi paling banyak sudah dalam keadaan BTA (+++) yaitu 18 orang dari 40 sampel $(45 \%)$, dan yang paling sedikit ditemukan adalah dalam keadaan BTA (+) sebanyak 8 orang (20\%). 


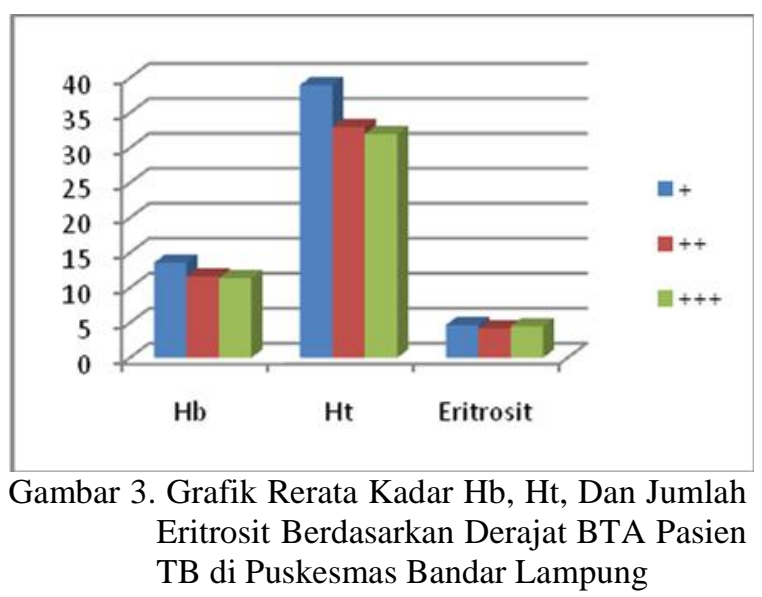

Pada tabel 3 dan gambar 3 nampak bahwa rerata kadar $\mathrm{Hb}$ tertinggi yaitu 13,6 $\mathrm{gr} / \mathrm{dL}$ terdapat pada kelompok sampel dengan keadaan BTA (+), sedangkan yang terendah terdapat pada kelompok sampel dengan keadaan BTA (+++) yaitu dengan rerata kadar $\mathrm{Hb} 11,4$ gr/dL. Nampak juga bahwa rerata $\mathrm{Ht}$ tertinggi terletak pada kelompok pasien dengan keadaan BTA (+) dengan kadar 39\% dan rerata terendah pada kelompok dengan keadaan BTA $(+++)$ yaitu $32 \%$. Sedangkan untuk rerata jumlah sel eritrosit (RBC) tertinggi ada pada kelompok sampel dengan BTA (+) yaitu 4,7 $\mathrm{juta} / \mathrm{mL}$ dan rerata terendah pada kelompok (++) yaitu 4,2 juta/mL.

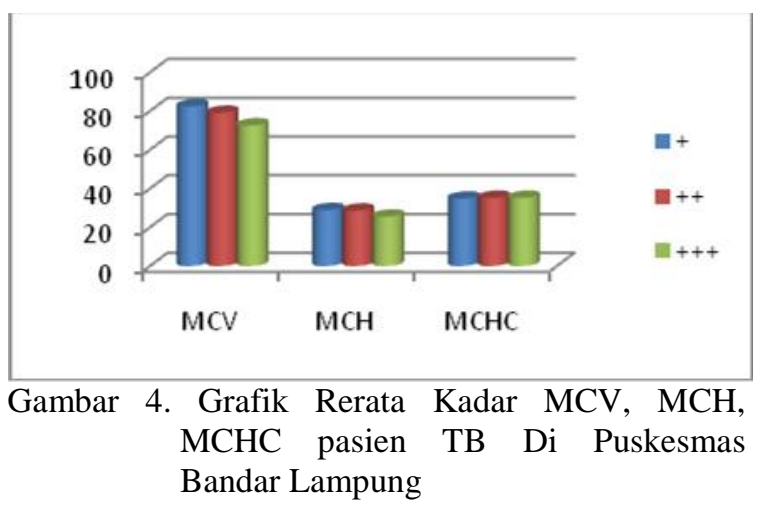

Pada gambar 4. nampak bahwa rerata nilai MCV tertinggi terdapat pada kelompok pasien TB dengan BTA $(+)$ yaitu $82,4 \mathrm{fL}$ dan terendah pada kelompok pasienTB dengan BTA (+++) yaitu 72,6 fL . Rerata nilai MCH tertinggi terdapat pada kelompok pasien TB dengan BTA (+) yaitu 28,9 pg dan terendah terdapat pada kelompok pasien TB dengan BTA (+++) yaitu 25,5 pg. Untuk rerata nilai MCHC didapatkan hasil yang sama pada kelompok pasien $\mathrm{TB}$ dengan $\mathrm{BTA}(++)$ dan $(+++)$ yaitu $35,2 \%$.

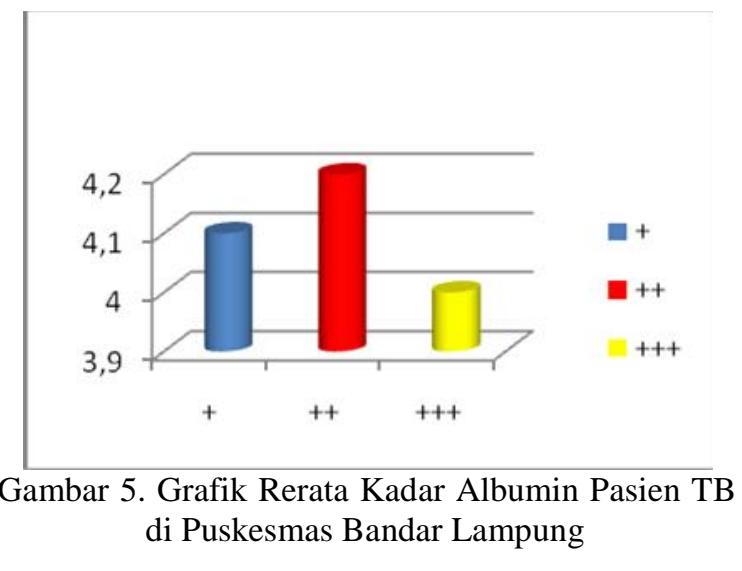

Pada gambar 5. nampak bahwa rerata kadar albumin tertinggi terdapat pada kelompok pasien TB dengan BTA (++), sedangkan kadar terendah terdapat pada kelompok pasien TB dengan BTA (+++).

Analisa bivariat pada hasil penelitian menggunakan uji One Way Anova digunakan untuk melihat ada tidaknya pengaruh tingkat infeksi Mycobacterium tuberculosis terhadap parameter hematologi anemia dan malnutrisi. Pada uji One WayAnova tahapan yang dilakukan adalah melihat distribusi data dan homogenitas data . Uji Normalitas Data menggunakan Uji Shapiro Wilk dengan hasil menunjukan data berdistribusi normal. Uji Homogenitas Data Menggunakan Uji Levene's. Hasil uji Levene's menunjukan nilai sig. ( $p$ value) > 0,05 pada seluruh variabel yang diteliti, sehingga dapat disimpulkan bahwa semua variabel memiliki varian yang sama/homogen. Oleh karena itu, uji Anova pada seluruh variabel di atas dapat dilanjutkan.

Tabel 4. Hasil Uji Statistik Seluruh Variabel pada Penderita BTA,,++++++

\begin{tabular}{|c|c|c|c|c|}
\hline \multirow{2}{*}{ Variabel } & \multicolumn{3}{|c|}{ Rerata \pm SD } & \multirow{2}{*}{$p$ value } \\
\hline & + & ++ & +++ & \\
\hline Eritrosit & $\begin{array}{c}4,74 \pm \\
0,46^{\mathrm{a}}\end{array}$ & $\begin{array}{c}4,18 \pm \\
0,65^{\mathrm{a}}\end{array}$ & $\begin{array}{c}4,49 \pm \\
0,71^{\mathrm{a}}\end{array}$ & 0,180 \\
\hline $\mathrm{Hb}$ & $\begin{array}{c}13,59 \\
\pm 2,07^{\mathrm{a}}\end{array}$ & $\begin{array}{c}11,59 \pm \\
1,76^{\mathrm{b}}\end{array}$ & $\begin{array}{c}11,38 \pm \\
1,91^{\mathrm{b}}\end{array}$ & $0,026^{*}$ \\
\hline $\mathrm{Ht}$ & $\begin{array}{c}39,25 \\
\pm 6,73^{\mathrm{a}}\end{array}$ & $\begin{array}{c}32,86 \pm \\
4,75^{\mathrm{b}}\end{array}$ & $\begin{array}{c}32,39 \pm \\
5,86^{\mathrm{b}}\end{array}$ & $0,019 *$ \\
\hline $\mathrm{MCV}$ & $\begin{array}{c}82,38 \\
\pm 6,63^{\mathrm{a}}\end{array}$ & $\begin{array}{c}79,10 \pm \\
4,35^{\mathrm{a}}\end{array}$ & $\begin{array}{c}72,56 \pm \\
10,07^{\mathrm{b}}\end{array}$ & $0,010^{*}$ \\
\hline $\mathrm{MCH}$ & $\begin{array}{r}28,88 \\
\pm 1,95^{\mathrm{a}} \\
\end{array}$ & $\begin{array}{c}28,57 \pm \\
3,29^{\mathrm{a}} \\
\end{array}$ & $\begin{array}{c}25,50 \pm \\
3,87^{\mathrm{b}}\end{array}$ & $0,019 *$ \\
\hline $\mathrm{MCHC}$ & $\begin{array}{c}34,75 \\
\pm \\
1,035^{\mathrm{a}}\end{array}$ & $\begin{array}{c}35,21 \pm \\
1,12^{\mathrm{a}}\end{array}$ & $\begin{array}{c}35,22 \pm \\
1,26^{\mathrm{a}}\end{array}$ & 0,604 \\
\hline Albumin & $\begin{array}{c}4,10 \pm \\
0,22^{\mathrm{a}}\end{array}$ & $\begin{array}{c}4,25 \pm \\
0,59^{\mathrm{a}}\end{array}$ & $\begin{array}{l}4,01 \pm \\
0,46^{\mathrm{a}}\end{array}$ & 0,389 \\
\hline
\end{tabular}

Keterangan: * menandakan adanya perbedaan yg signifikan berdasarkan uji One Way Anova pada $\alpha$ $5 \%$. Nilai rerata yang diikuti huruf berbeda pada 
kolom yang sama menandakan adanya perbedaan yang signifikan berdasarkan uji LSD pada $\alpha 5 \%$.

\section{Pembahasan}

Berdasarkan hasil uji deskriptif di atas, diketahui bahwa penderita BTA + berjumlah 8 orang, ++ berjumlah 14 orang dan +++ berjumlah 18 orang. Rerata jumlah eritrosit tertinggi dimiliki oleh penderita BTA $+(4,7$ juta sel), sedangkan yang terendah dimiliki oleh penderita BTA ++ (4,2 juta sel). Hasil tersebut juga menunjukan bahwa bertambahnya derajat BTA, tidak diikuti oleh menurunnya jumlah eritrosit. Rerata kadar $\mathrm{Hb}$ terendah ditemukan kelompok +++ (11,4 g/dL), sedangkan kadar $\mathrm{Hb}$ tertinggi ditemukan pada kelompok +. Seperti kadar $\mathrm{Hb}$, kadar $\mathrm{Ht}$, nilai MCV dan $\mathrm{MCH}$ terendah juga ditemukan pada kelompok +++, dan kadar tertinggi ditemukan pada kelompok +. Pada kadar $\mathrm{Hb}, \mathrm{Ht}, \mathrm{MCV}$ dan $\mathrm{MCH}$, penurunan kadar yang terjadi, tampaknya seiring dengan peningkatan derajat BTA, semakin tinggi derajat BTA maka kadar nya akan semakin rendah. Hasil uji deskriptif juga menunjukan bahwa nilai MCHC tertinggi ditemukan pada penderita dengan BTA +++, dan yang terendah ditemukan pada penderita dengan BTA + .

Hasil uji One way Anova pada jumlah eritrosit menunjukan nilai sig. sebesar 0,180 $(p>0,05)$. Sehingga dapat disimpulkan bahwa tidak terdapat perbedaan rerata jumlah eritrosit yang bermakna antara penderita BTA,+++ dan +++ .

Hasil uji One way Anova pada hemoglobin $(\mathrm{Hb})$ menunjukan nilai sig. sebesar $0,026(p<0,05)$, sehingga dapat disimpulkan bahwa terdapat perbedaan rerata kadar $\mathrm{Hb}$ yang bermakna paling tidak antara 2 kelompok penderita $\mathrm{BTA}+,++$ dan +++ . Uji kemudian dilanjutkan dengan uji Post Hoc LSD untuk mengetahui kelompok mana yang memiliki perbedaan. Hasil uji Post Hoc LSD menunjukan rerata kadar $\mathrm{Hb}$ pada kelompok penderita BTA + lebih tinggi secara signifikan bila dibandingkan dengan pada kelompok BTA positif ++ dan +++ . Hasil uji juga menunjukan bahwa rerata kadar $\mathrm{Hb}$ pada penderita BTA ++ dan +++ tidak berbeda secara signifikan.

Hasil uji One way Anova pada hematokrit $(\mathrm{Ht})$ menunjukan nilai sig. sebesar $0,019(p<0,05)$, sehingga dapat disimpulkan bahwa terdapat perbedaan rerata nilai $\mathrm{Ht}$ yang bermakna paling tidak antara 2 kelompok penderita BTA,+++ dan +++ . Uji kemudian dilanjutkan dengan uji Post Hoc LSD untuk mengetahui kelompok mana yang memiliki perbedaan. Seperti halnya kadar $\mathrm{Hb}$, hasil uji Post Hoc LSD menunjukan rerata nilai Ht pada kelompok penderita BTA + lebih tinggi secara signifikan bila dibandingkan dengan pada kelompok BTA ++ dan BTA +++. Hasil uji juga menunjukan bahwa rerata kadar $\mathrm{Ht}$ pada penderita BTA ++ dan BTA +++ tidak berbeda secara signifikan.

Hasil uji One Way Anova pada MCV menunjukan nilai sig. sebesar 0,010 $(p<0,05)$, sehingga dapat disimpulkan bahwa terdapat perbedaan rerata nilai MCV yang bermakna paling tidak antara 2 kelompok penderita BTA ,,++++++ . Uji kemudian dilanjutkan dengan uji Post Hoc LSD untuk mengetahui kelompok mana yang memiliki perbedaan. Hasil uji Post Hoc LSD menunjukan tidak adanya perbedaan rerata nilai MCV yang bermakna antara penderita $\mathrm{BTA}+$ dan $\mathrm{BTA}++$, namun nilai MCV penderita BTA + lebih tinggi secara signifikan bila dibandingkan dengan penderita BTA +++. Nilai MCV pada penderita BTA ++ juga lebih tinggi secara signifikan bila dibandingkan dengan penderita BTA +++.

Hasil uji One Way Anova pada $\mathrm{MCH}$ menunjukan nilai $\mathrm{p}$ value sebesar 0,019 $(p<0,05)$, sehingga dapat disimpulkan bahwa terdapat perbedaan rerata nilai $\mathrm{MCH}$ yang bermakna paling tidak antara 2 kelompok penderita $\mathrm{BTA}+, \quad++, \quad+++$. Selanjutnya dilakukan uji Post Hoc LSD untuk mengetahui kelompok mana yang memiliki perbedaan nilai MCH. Seperti pada nilai MCV, hasil uji Post Hoc LSD juga tidak menunjukan adanya perbedaan rerata nilai $\mathrm{MCH}$ yang bermakna antara penderita BTA + dan ++ , namun nilai $\mathrm{MCH}$ penderita $\mathrm{BTA}+$ lebih tinggi secara signifikan bila dibandingkan dengan penderita BTA +++. Nilai MCH pada penderita BTA ++ juga diketahui lebih tinggi secara signifikan bila dibandingkan dengan penderita BTA +++.

Hasil uji One Way Anova pada MCHC didapatkan nilai sig. sebesar 0,604 $(p>0,05)$, sehingga dapat disimpulkan bahwa tidak terdapat perbedaan rerata nilai MCHC yang bermakna pada penderita BTA,+++ dan +++ .

Hasil uji One Way Anova pada albumin didapatkan nilai sig. sebesar 0,389 $(p>0,05)$, sehingga dapat disimpulkan bahwa tidak terdapat perbedaan rerata kadar albumin serum yang bermakna pada penderita BTA,+++ dan +++ .

Hasil penelitian menunjukkan bahwa terdapat kejadian anemia sebesar $80 \%$ pada pasien TB di puskesmas Bandar Lampung. Data hasil penelitian juga menunjukkan kejadian 
malnutrisi pada pasien TB di puskesmas Bandar Lampung hanya $7,5 \%$ dan yang tidak mengalami malnutrisi sebanyak 82,5. Bedasarkan hasil penelitan (Purnasari, 2011) tuberkulosis paru anak yang belum berobat/baru terdiagnosis dan mengalami anemia sebanyak $30,77 \%$ (4 anak), berada dalam fase awal dan mengalami anemia sebanyak 23,08 (3 anak), dan paling banyak berada dalam fase lanjutan, yaitu sebanyak 46,15\% (6 anak) yang mengalami anemia. Bedasarkan penelitian (Sadewo, 2012) didapatkan sebanyak $74 \%$ pasien dengan TB dengan anemia dan 26\% pasie TB dengan tidak anemia.

Berdasarakan hasil penelitian tersebut maka dapat dikatakan bahwa kejadian anemia yang terjadi pada paien TB di puskesmas Bandar Lampung yng sebabkan oleh kondisi penyakit yang berhubungan dengan peradangan, dan yang berlangsung lebih dari 1 atau 2 bulan (Anemia penyakit kronis). Anemia penyakit kronis (disebut juga anemia peradangan kronis) merupakan kondisi umum yang ditandai oleh anemia, penurunan besi serum, dan cadangan besi yang masih memadai dalam sumsum tulang ( Kiswari, 2014).

Simpulan dari hasil penelitian ini adalah tidak ada pengaruh infeksi Mycobacterium tuberculosis (berdasarkan derajat BTA) terhadap jumlah eritrosit pasien $\mathrm{TB}$ di puskesmas Bandar Lampung. Ada pengaruh yang signifikan infeksi Mycobacterium tuberculosis (berdasarkan derajat BTA) terhadap kadar hemoglobin $(\mathrm{Hb})$ pasien $\mathrm{TB}$ di puskesmas Bandar Lampung. Ada pengaruh yang signifikan infeksi Mycobacterium tuberculosis (berdasarkan derajat BTA) terhadap kadar hematokrit (Ht) pasien TB di puskesmas Bandar Lampung. Ada pengaruh yang signifikan infeksi Mycobacterium tuberculosis (berdasarkan derajat BTA) terhadap nilai MCV pasien TB di puskesmas Bandar Lampung. Ada pengaruh yang signifikan infeksi Mycobacterium tuberculosis (berdasarkan derajat BTA) terhadap nilai $\mathrm{MCH}$ pasien TB di puskesmas Bandar Lampung. Tidak ada pengaruh infeksi Mycobacterium tuberculosis (berdasarkan derajat BTA) terhadap nilai MCHC pasien Tidak ada pengaruh infeksi Mycobacterium tuberculosis (berdasarkan derajat BTA) terhadap kadar albumin pasien TB di puskesmas Bandar Lampung.
Hasil penelitian menunjukkan bahwa 80\% pasien TB di puskesmas Bandar Lampung mengalami anemia, oleh sebab itu disarankan untuk dilaksanakan penanganan segera terhadap pasien TB yang mengalami anemia agar tidak menambah berat gejala penyakit pada pasien TB.Dilakukan penelitian lebih lanjut dalam usaha mendapatkan/mencari pengobatan alternatif untuk menanggulangi kejadian anemia pada penderita TB di puskesmas Bandar Lampung.

\section{Daftar Pustaka}

Ida F, Grace E.S. Kadar Hemoglobin $(\mathrm{Hb})$ Penderita TB Paru Dalam Masa Terapi OAT (Obat Anti Tuberkulosis)di Puskesmas Haji Abdul Halim Hasan Binjai. Medan.

Kementrian Kesehatan RI, 2017, Profil Kesehatan Indonesia 2017. Tersedia (http://www.depkes.go.id/resources/down load/pusdatin/profil-kesehatanindonesia/Profil-Kesehatan-Indonesiatahun-2017.pdf) [24 Oktober 2018]

Kementrian Kesehatan RI, 2018, Infodatin Tuberkulosis 2018, Tersedia (http://www.depkes.go.id/folder/view/01/ structure-publikasi-pusdatin-infodatin.html) [24 Oktober 2018]

Kiswari, Rukman, 2014, Hematologi \& Tranfusi, Jakarta: Erlangga. $363 \mathrm{Hal}$

Martina, Adinda Devi. 2012. Hubungan usia, jenis kelamin dan status nutrisi dengan kejadian anemia pada pasien tuberkulosis di RSUP DR. Kariadi Semarang. Jurnal Kesehatan Universitas Lampung, Tersedia (https://ejournal3.undip.ac.id/index.php/ medico/article/view/1443) [4 Maret 2019]

Nasution, Sheba Denisica. 2015. Malnutrisi dan Anemia pada Penderita Tuberkulosis Paru. Jurnal Kesehatan Universitas Lampung, Tersedia (http://juke.kedokteran.unila.ac.id/index. php/majority/article/view/1469) $[15$ November 2018]

Prastowo, Agus, dkk. 2016. Efektifitas pemberian ekstra putih telur terhadap peningkatan kadar albumin dan IL-6 
pada pasien tuberkulosis dengan hipoalbumin. Jurnal kesehatan UMS, available at: http://journals.ums.ac.id/index.php/JK/art icle/view/3373(diakses pada 2 Januari 2019)

Price, A Sylvia. Wilson, Mc C Lorraine. 2006. Patofisiologi : Konsep Klinis Prosesproses Penyakit, E/6, Vol.2. Jakarta : Penerbit Buku Kedokteran EGC

Purnasari, Galih. 2011 Anemia pada Penderita Tuberkulosis Paru Anak dengan Berbagai Status Gizi dan Asupan Gizi. Semarang: Universitas Diponegoro available

at http://eprints.undip.ac.id/32592/1/394_G alih_Purnasari_G2C007032.pdf (diakses pada 10 Oktober 2019)

Sadewo, S. 2017. Gambaran Status Anemia pada Pasien Tuberkulosis Paru. Pontianak: Universitas Tanjungpura available at: https://media.neliti.com/media/publicatio ns/193104-ID-gambaran-status-anemiapada-pasien-tuber.pdf (diakses pada 10 Oktober 2019)

Sadikin, Dr.H Mohamad. DSc. Biokimia darah. 2010. Jakarta : Widya Medika.

Shiddiqi, Khairil Umam A. 2016. Efek kadar albumin terhadap perbaikan klinis pasien tuberkulosis di poli instalasi pelayanan tuberkulosis terpadu (PTT) Rumah sakit umum daerah Dr. Zainoel Abidin Banda Aceh. Disertasi dan Thesis Elektronik Unsyiah, available at: http://etd.unsyiah.ac.id/baca/index.php?id $=28862$ \&page $=1$ (diakses pada pada 2 Januari 2019)

Sibuea, Dr. W. Herdin, Dr. M, Marulam. dkk. Ilmu penyakit dalam. 2005. Jakarta: PT Rineka Cipta.

Simbolon, Harsa T. Lombo, Julia C, dkk. 2016. Hubungan indeks massa tubuh dengan kadar albumin pada pasien tuberkulosis paru. 2016. Fakultas Kedokteran Universitas Sam Ratulangi Manado, Bagian ilmu penyakit dalam BLU RSUP Prof. DR. R. D. Kandou Manado. 